\title{
Biochar-Residue Integrated Approach as a Conservation Agriculture Strategy for Climate Smart Farming
}

\author{
Rishikesh Singh ${ }^{1 *}$, Pratap Srivastava ${ }^{2}$, Pardeep Singh ${ }^{3}$, Rahul Bhadouria ${ }^{4}$, Shikha Singh ${ }^{1}$, Hema Singh ${ }^{4}$ and AS \\ Raghubanshi ${ }^{1}$ \\ ${ }^{1}$ Institute of Environment \& Sustainable Development (IESD), Banaras Hindu University, India
}

${ }^{2}$ Department of Chemical Engineering \& Technology, Indian Institute of Technology (IIT-BHU), India

${ }^{3}$ Department of Environmental Studies, University of Delhi, India

${ }^{4}$ Ecosystems Analysis Laboratory, Banaras Hindu University, India

Submission: April 13, 2017; Published: May 04, 2017

"Corresponding author:Rishikesh Singh, Institute of Environment \& Sustainable Development (IESD), Banaras Hindu University, Varanasi-221005, India, Tel: +91-9621148840; Email: rishikesh.iesd@gmail.com

\begin{abstract}
Crop residue burning leads to release of various pollutants along with photo-synthetically locked CO2 back to the atmosphere in a very short time. Residue retention provides various ecosystem services with a partial C sequestration potential. However, increasing emissions from agro-ecosystems and decreasing soil health status lead to collaborative research on conservation agriculture and soil supplement addition. In this regard, partial crop residue retention and partial residue conversion to bio char could be a potential strategy for mitigating climate change in addition to felicitation of native SOM and soil health as well as improved fertilizer use efficiency.
\end{abstract}

\section{Introduction}

The exhaustive agricultural practices for meeting the dietary demand of ever-growing population have been well quoted as a potential cause of diminishing various components of agroecosystems worldwide [1,2]. In addition, the decrease in native soil organic matter (SOM) content, disturbed soil above- and below-ground activities and increasing greenhouse gaseous emissions from such ecosystems are the hot topics of research in $21^{\text {st }}$ century [3]. Various soil adoptive management strategies have been suggested and some are applied for improving soil environment by regaining SOM and decreasing GHG emissions via improved above- and below-ground activities [4,5]. Important soil management strategies include conservation agriculture practices [6,7], organic farming [8-10], genetically improved crop varieties [11], soil amendments [4] (e.g., sewage sludge, fly-ash, bio char, bio fertilizers, etc.), and improved use of agrochemicals and use of slow-release fertilizers [4], etc. However, all these systems are interrelated in various ways; therefore, an integrative approach should be applied for continuous monitoring along with differing background geographic details.

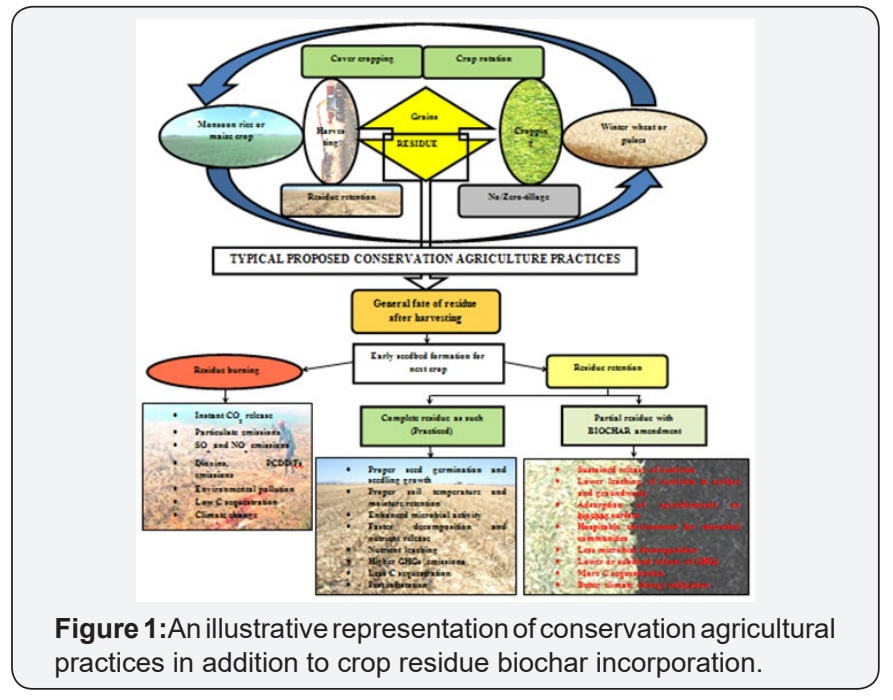

In the present scenario, residue generation and its management is the hot topic of research [4,12-14]. In addition, crop residue, earlier considered as waste, is now a precious resource due to its multifaceted uses $[15,16]$. Residue burning and 
its post consequences give further impetus to the policy makers to take stress on its management $[17,18]$ (Figure 1). Potential measures for residue management include its utilization for livestock feed, incorporation in conservation agriculture system, as feedstock for bio fuel generation especially in biochemical and thermo chemical processes $[19,20]$. Conservation agriculture system including a package of reduced tillage, residue retention and crop rotation practices has been foreseen as one of the indigenous soil improvement strategy $[9,10]$ (Figure 1).

The mechanism involved includes increased SOM content in its vicinity due to faster decomposition rate of crop residue in addition to improved soil physical, chemical and biological properties [21,22]. In addition, combined harvesting system and short preparatory period between two crops lead farmers to openly burn substantial crop residues [17]. This further adds various pollutants and GHGs to the environment with quick release of photo-synthetically trapped $\mathrm{CO}_{2}[17,18]$. Likewise, residue retention and its degradation lead to release of nutrients as well as gaseous emissions and pest infestations $[16,22,23]$. These shortcomings in conservation agriculture system and residue management pave the way for certain modulation in it by harmonizing the balance between soil health and crop yield along with reduced GHGs emissions and C sequestration. Such processes include utilization of crop residue as feedstock for bio fuel production through biochemical and thermo chemical pathways [14,19,20]. Recently, research communities have focused on thermo chemical processes like pyrolysis and gasification due to production of carbon neutral or negative fuel as compared to the other processes [19].

Bio char, a thermo chemical by-product of biomass, has been recommended as a potential soil ameliorant because of its potential to improve soil physical, chemical and biological properties [24-27]. In addition, it has potential to improve fertilizer use efficiency, reduction in pesticides use and groundwater pollution through the adsorption of such agrochemicals on the highly available bio char surfaces [28]. The substantially available crop residues as well as weeds have been regarded as the cheap and best available feedstock source for bio char formation especially in developing countries [27]. This paves the way for its inclusion in conservation agriculture systems as partial residue retention with partial bio char application. The advantage of this system would be more improved soil environment in addition to mitigation in climate change due to locking of a major photo-synthetically trapped atmospheric $\mathrm{CO}_{2}$ [24,29] (Figure 1). As estimated by Lehmann et al. [23] the retention of $\mathrm{C}$ through biomass burning, residue retention and bio char application can be 3, 10-20 and 50\%, respectively in 5-10 years.

However, conservation agriculture policies are facing several constrains like crop residue retention compromising feedstock for livestock population, crop residue retention causing problems in agronomic practices, and its removal for bio char formation leading to SOM reduction and soil erosion $[6,13,30]$. In practical terms, a balanced approach as discussed by BlancoCanqui \& Lal [16] for crop residue retention and removal could lead to felicitation of native SOM content for various soil types in addition to fulfill the dietary requirement of livestock. What is needed to be established is the integration of conservation agriculture along with bio char technology for various soil types in Indian subcontinent. A generalized model of partial residue retention and bio char addition has been presented in Figure 1. Thus, there is a need of exploration of such versatile practices for conservation agriculture systems through proper understanding between various stakeholders such as farmers, agronomists, environmentalists and biochar technologists. In addition, such modulations could be well studied for problem soils having less productivity, significant emissions, and greater scope of soil amendment additions.

\section{Acknowledgement}

3Authors are highly thankful to Prof. J.S. Singh, Emeritus Professor, Department of Botany, Institute of Science, BHU, Varanasi, for his valuable suggestions.

\section{References}

1. Godfray HC, Beddington JR, Crute IR, Haddad L, Lawrence D, et al. (2010) Food security: the challenge of feeding 9 billion people. Science 327(5367): 812-818.

2. Lal R (2011) Sequestering carbon in soils of agro-ecosystems. Food Policy 36: S33-S39.

3. Abhilash PC, Dubey RK (2014) Integrating aboveground-belowground responses to climate change. Current Science 106(12): 1637-1638.

4. Delgado JA, Groffman PM, Nearing MA, Goddard T, Reicosky D, et al. (2011) Journal of Soil and Water Conservation 66(4): 118A-129A.

5. Abhilash PC, Singh HB, Dubey RK, Verma JP (2013) Adaptive soil management. Current Science 104(10): 1275-1276.

6. Kassam A, Friedrich T, Shaxson F, Pretty J (2009) International Journal of Agricultural Sustainability 7(4): 292-320.

7. Tullberg J (2010) Reduce soil damage for more sustainable crop production. Nature 466: 920.

8. Singh YV (2013) Crop and water productivity as influenced by rice cultivation methods under organic and inorganic sources of nutrient supply. Paddy Water and Environment 11(1): 531-542.

9. Robertson F, Nash D (2013) Limited potential for soil carbon accumulation using current cropping practices in Victoria, Australia. Agriculture, Ecosystems and Environment 165(15): 130-140.

10. Thierfelder C, Cheesman S, Rusinamhodzi L (2013) Benefits and challenges of crop rotations in maize-based conservation agriculture (CA) cropping systems of southern Africa. International Journal of Agricultural Sustainability 11(2): 108-124.

11. Murphy K, Campbell KG, Lyon SR, Jones SS (2007) Evidence of varietal adaptation to organic farming systems. Field Crops Research 102: 172177.

12. Lal, R (2008) Crop residues as soil amendments and feedstock for bioethanol production. Waste Management 28(4): 747-758.

13. Lal R, Pimentel D (2009) Biofuels: Beware Crop Residues. Science 32(5958): 1345-1346. 
14. Tilmann D, Socolow R, Foley JA, Hill J, Larson E, et al. (2009) Energy. Beneficial biofuels--the food, energy, and environment trilemma. Science 325(5938): 270-271.

15. Lal R (2004) Is crop residue a waste? Journal of Soil and Water Conservation 59(6): 136A-139A.

16. Blanco-Canqui H, Lal R, Geoderma (2007) Soil and crop response to harvesting corn residues for biofuel production 141(3-4): 355-362.

17. Singh N (2013) Thesis submitted to Thapar University, Patiala, USA.

18. Pandey K, Sahu LK (2014) Emissions of volatile organic compounds from biomass burning sources and their ozone formation potential over India. Current Science 106(9): 1270-1279.

19. Lehmann J (2007) A handful of carbon. Nature 447(7141): 143-144

20. Bonin C, Lal R (2012) Bioethanol Potentials and Life-Cycle Assessments of Biofuel Feedstocks. Critical Reviews in Plant Sciences 31(4): 271289.

21. Singh H, Pathak P, Kumar M, Raghubanshi AS (2008) Carbon sequestration potential of Indo-Gangetic agroecosystem soils. Tropical Ecology 52(2): 223-228.

This work is licensed under Creative Commons Attribution 4.0 License

DOI: $10.19080 /$ ARTOAJ.2017.06.555693
22. Karlen DL (2009) Environmental Science and Technology 43: 80118015.

23. Lehmann J, Gaunt J, Rondon M (2006) Mitigation and Adaptation Strategies for Global Change 11(2): 395-419.

24. Woolf D (2008) University of Swansea, UK.

25. Lehmann J, Joseph S (2009) Biochar for Environmental Management: Science and Technology, Earthscan, USA.

26. Jha P, Biswas AK, Lakaria BL, Subba Rao A (2010) Biochar in agricultureprospects and related implications, Current Science 99(9): 1218-1225.

27. Mandal S, Ramkrushna GI, Verma BC, Das A (2013) Biochar: an innovative soil ameliorant for climate change mitigation in NE India, Current Science 105(5): 568-569.

28. Lehmann J (2011) Soil Biology and Biochemistry 43: 1812-1836.

29. Woolf D, Amonette JE, Street-Perrott FA, Lehmann J, Joseph S (2010) Sustainable biochar to mitigate global climate change, Nat Commun 1 : 56.

30. Lal R (2007) CSA News. 52(5): 12-13

Your next submission with Juniper Publishers will reach you the below assets

- Quality Editorial service

- Swift Peer Review

- Reprints availability

- E-prints Service

- Manuscript Podcast for convenient understanding

- Global attainment for your research

- Manuscript accessibility in different formats

(Pdf, E-pub, Full Text, Audio)

- Unceasing customer service

Track the below URL for one-step submission https://juniperpublishers.com/online-submission.php 